\title{
Sosialisasi Anemia Kehamilan pada Ibu Hamil Trimester II dan III
}

\author{
Yanuar Eka Pujiastutik ${ }^{1 *}$, Rosi Candra Refina ${ }^{2}$, Anggina Firdausi ${ }^{3}$, Ellma Tri Yuliana ${ }^{4}$ \\ ${ }_{1,2,3,4}$ S1 Keperawatan, Fakultas Ilmu Kesehatan, Institut Ilmu Kesehatan Bhakti Wiyata \\ * yanuar.eka@iik.ac.id
}

Received 21 August 2019; Accepted 28 August 2019; Published 5 September 2019

\begin{abstract}
ABSTRAK
Anemia merupakan kondisi rendahnya kadar Hb seseorang (WHO 2012). Ibu hamil dikatakan mengalami anemia jika kadar $\mathrm{Hb}<110 \mathrm{~g} / \mathrm{l}$ selama masa kehamilan. Efek anemia kehamilan bagi ibu jika kadar hemoglobin kurang dari $6 \mathrm{~g} / \mathrm{dl}$, dan tergolong anemia berat maka dapat menimbulkan komplikasi pada ibu hamil dan janin. Anemia berat menunjukkan gejala jantung berdebar, takikardia, sesak napas, dekompensasi kordis dan gagal jantung yang mungkin berakibat fatal. Diperlukan upaya untuk meningkatkan kadar hemoglobin selain suplementasi dan peningkatan pengetahuan, yaitu dengan penyuluhan kesehatan dalam bentuk kegiatan yang dilakukan dalam kegiatan pengabdian masyarakat ini adalah memberikan penyuluhan kesehatan tentang pengertian anemia, klasifikasi anemia, sumber zat besi, gejala anemia, dan bahaya anemia bagi janin di Puskesmas Sukorame Kota Kediri. Jumlah peserta pada kegiatan ini adalah sebanyak 10 ibu hamil trimester II dan III. Hasil pengetahuan yang diperoleh sebelum dilakukan wawancara ke ibu hamil adalah sejumlah 2 dari 10 ibu mengatakan bahwa tidak mengetahui dan dan belum paham dampak anemia bagi janin, dari hasil ini bahwa pengetahuan Ibu tentang anemia kehamilan tergolong sangat rendah. Setelah dilakukan penyuluhan, pengetahuan ibu hamil tentang anemia di evaluasi dengan memberikan pertanyaan kembali pada ibu-ibu untuk mengetahui adanya perubahan pengetahuan setelah diberikan penyuluhan, hasil yang diperoleh menunjukkan bahwa 9 dari 10 ibu hamil bahwa pengetahuan Ibu tentang anemia kehamilan tergolong baik.
\end{abstract}

Kata kunci: Anemia, kehamilan, pengetahuan

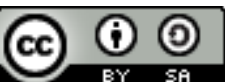

This is an open-acces article distributed under the terms of the Creative Commons Attribution-ShareAlike 4.0 International License.

\section{PENDAHULUAN}

Meningkatkan derajat kesehatan wanita dan mennekan angka kematian ibu telah menjadi prioritas kesehatan publik untuk agenda Perserikatan Bangsa-Bangsa (PBB). Beragam cara dilakukan untuk mengurangi mortalitas dan morbiditas ibu, namun kenyataannya di negara-negara berkembang masih dibebani dengan mortalitas dan morbiditas ibu yang tinggi. Sekitar 830 ibu meninggal disebabkan karena adanya komplikasi dalam kehamilan atau persalinan di seluruh dunia perharinya. Tahun 2015, sekitar $303.000 \mathrm{ibu}$ meninggal yang terjadi saat hamil ataupun saat persalinan. Penyebab kematian ini terjadi karena pengetahuan ibu yang rendah yang sebenarnya hal tersebut bisa dicegah. Kerangka kerja pengembangan dunia telah bergeser dari Tujuan Membangunan Milenium (MDGs) untuk Tujuan Pembangunan Berkelanjutan SDGs) (WHO, 2016). Dalam periode Sustainable Development Goals (SDGs), tujuannya adalah untuk mengurangi Maternal Mortality Rate (MMR) menjadi kurang dari 70 dari 100.000 angka kelahiran hidup. Target MDGs tahun 2030, tidak ada negara yang memiliki kematian ibu lebih dari 140 dari 100.000 angka kelahiran hidup. MMR adalah jumlah ibu yang saat 
kehamilan mengalami kematian, persalinan, dan persalinan yang disebabkan oleh komplikasi kehamilan, penyulit persalinan, ataupun penyulit setelah melahirkan tetapi tidak untuk penyebab lain seperti kecelakaan, jatuh, dan lain-lain dalam setiap 100.000 hidup (Departemen Kesehatan Republik Indonesia, 2015).

Sebagian besar komplikasi pada ibu berkembang selama kehamilan yang sebenarnya bisa dicegah atau diobati sebelum menyebabkan keadaan yang lebih buruk atau bahkan memburuk selama kehamilan. Menurut WHO tahun 2016, ada lima penyebab terbesar komplikasi yang menyebabkan sekitar 75\% dari kematian ibu antara lain perdarahan hebat, infeksi yang terjadi setelah melahirkan, preeklampsia dan eklampsia, komplikasi persalinan, aborsi yang berbahaya (WHO, 2016). Manuaba (2010) mengatakan bahwa anemia dalam kehamilan akan meningkatkan resiko perdarahan selama persalinan. Anemia merupakan kelainan darah yaitu penurunan sirkulasi total sel darah merah yang terjadi pada ibu hamil. Menurut WHO, anemia terjadi ketika Hemoglobin $(\mathrm{Hb})$ konsentrasi dalam darah perifer adalah $11 \mathrm{gm} / \mathrm{dl}$ atau kurang. Penyebab yang sering terjadi pada anemia kehamilan adalah kekurangan zat besi, jarang disebabkan oleh kekurangan asam folat. Dalam beberapa populasi, $80 \%$ wanita hamil mengalami anemia (Prawirohardjo, 2014). Anemia ringan tidak berpengaruh pada kehamilan dan persalinan, kecuali pada ibu yang mempunyai kadar zat besi rendah. Anemia sedang tejadi kelemahan, kurangnya energi, kelelahan. Anemia berat menunjukkan gejala jantung berdebar, takikardia, sesak napas, dekompensasi kordis dan gagal jantung yang mungkin berakibat fatal. Meningkatnya insiden persalinan prematur $(28,2 \%)$, pre-eklampsia $(31,2 \%)$ dan sepsis telah dikaitkan dengan anemia.

Hasil penelitian Fakultas Kedokteran di seluruh Indonesia menyebutkan bahwa angka kejadian anemia ibu hamil di Indonesia adalah 50-63\%. Penyebab paling besar anemia kehamilan adalah kekurangan zat besi yang faktor pencetusnya mencakup grande multipara, status sosial ekonomi rendah, malaria, infeksi HIV dan jarak dari anak pertama dan seterusnya yang tidak teratur (Irianti dkk, 2014). Upaya pemerintah untuk mengurangi angka kejadian anemia dalam kehamilan yaitu dengan menjalankan program Pelayanan Antenatal Terpadu yang didalamnya termasuk pelayanan konseling kepada ibu hamil untuk membantu mengatasi masalah tentang masalah gizi selama kehamilan, pemeriksaan kadar hemoglobin masing-masing minimal 1 kali pada trimester 1 dan trimester 3, dan selama kehamilan diberi tablet Fe dan asam folat minimal 90 tablet (PERMENKES RI, 2014). Soekanto (2002) dalam Lestari (2015) menjelaskan bahwa pengetahuan (knowledge) atau kognitif merupakan ranah untuk mengidentifikasi hal yang sangat penting dalam membentuk tindakan seseorang (overt behaviour). Berdasarkan hasil penelitian oleh Purbadewi dan Ulfie (2013) terdapat hubungan yang bermakna antara pengetahuan ibu hamil yang membahas tentang ruang lingkup anemia dengan besarnya angka kejadian anemia dalam kehamilan.

Angka kejadian anemia pada kehamilan menurut data Riskesdas tahun 2018 cukup tinggi dan mengalami peningkatan dari 37,1\% tahun 2013 menjadi 48,9\% tahun 2018. Menurut WHO (2010), angka kejadian anemia pada ibu hamil di Indonesia tergolong moderate public health problem $(20,0-$ 39,9\%). Data yang diambil dari Puskesmas Sukorame bahwa jumlah anemia dalam kehamilan pada akhir bulan April 2019 sebanyak 15. Berdasarkan studi pendahuluan di Puskesmas Sukorame dengan melakukan wawancara terhadap $10 \mathrm{ibu}$ hamil tentang pengertian, penyebab dan bahaya anemia kehamilan yaitu pada ibu dan janin didapatkan data sebanyak 8 orang $(80 \%)$ belum memahami anemia dari pertanyaan yang diajukan oleh peneliti dengan benar dan sebanyak 2 orang (20\%) sudah menjawab dengan benar.

Berdasarkan latar belakang, peneliti tertarik untuk melakukan pengabdian masyarakat melalui pendidikan kesehatan dengan judul sosialisasi anemia kehamilan pada ibu hamil trimester II dan III di Puskesmas Sukorame Kota Kediri.

\section{BAHAN DAN METODE}

Pelaksanaan sosialisasi dilakukan di rumah warga selama 1 hari dengan menggunakan media penyuluhan berupa leaflet dan flip chart. Adapun materi sosialisasi antara lain pengertian anemia, klasifikasi anemia kehamilan, penyebab anemia, gizi yang tepat untuk anemia,dan bahaya anemia bagi janin. Sampel yang digunakan sebanyak $10 \mathrm{ibu}$ hamil dengan anemia dari total populasi 15 dengan kategori anemia ringan dan sedang. Waktu sosialisasi dilakukan selama 2 jam dengan tujuan tingkat

\section{Journal of Community Engagement in} Health 
pengetahuan ibu tersebut dapat meningkat. Instrumen yang digunakan dalam sosialisasi ini berupa kuesioner untuk menggali seberapa tinggi tingkat pengetahuan ibu tentang anemia kehamilan. Hasil pretest dan posttest sosialisasi ini kemudian akan dikategorikan menjadi kategori baik, kategori cukup, dan kategori kurang.

\section{HASIL}

Hasil sosialisasi anemia kehamilan menurut kategori pengetahuan, pekerjaan, dan usia disajikan dalam tabel dibawah ini:

Tabel 1.1 Hasil Sosialisasi Anemia Kehamilan

\begin{tabular}{ccccc}
\hline No & Responden & $\begin{array}{c}\text { Kategori pengetahuan } \\
\text { pretest }\end{array}$ & $\begin{array}{c}\text { Kategori } \\
\text { pengetahuan posttest }\end{array}$ & Pekerjaan \\
\hline 1 & A & Kurang & Cukup & Tidak bekerja \\
\hline 2 & B & Kurang & Cukup & Tidak bekerja \\
\hline 3 & C & Kurang & Baik & Tidak bekerja \\
\hline 4 & D & Kurang & Baik & Wiraswasta \\
\hline 5 & E & Kurang & Baik & Wiraswasta \\
\hline 6 & F & Kurang & Baik & Tidak bekerja \\
\hline 7 & G & Kurang & Baik & Tidak bekerja \\
\hline 8 & H & Kurang & Baik & Tidak bekerja \\
\hline 9 & I & Kurang & Baik & Tidak bekerja \\
\hline 10 & J & Cukup & Baik & Swasta \\
\hline
\end{tabular}

Berdasarkan tabel diatas kesimpulannya dari 10 ibu hamil dengan anemia sebelum dilakukan sosialisasi anemia tingkat pengetahuan kurang sebanyak $90 \%$ artinya belum memahami tentang anemia kehamilan, sedangkan setelah dilakukan sosialisasi selama 2 jam tingkat pengetahuan menjadi kategori baik dengan jumlah sebanyak $80 \%$.

Usia ibu hamil rata-rata dalam rentang 20-35 tahun dengan variasi pekerjaan 70\% tidak bekerja dengan kategori pengetahuan setelah dilakukan sosialisasi menjadi baik dan 30\% status pekerjaannya adalah wiraswasta dan swasta dengan kategori pengetahuan cukup.

\section{PEMBAHASAN}

Hasil tingkat pengetahuan tentang anemia ini dibagi menjadi tiga kategori yaitu kategori pengetahuan baik, pengetahuan cukup dan pengetahuan kurang. Hasil pengabdian masyarakat diketahui bahwa sosialisasi anemia kehamilan sebelum dilakukan sosialisasi berpengetahuan kurang sebanyak 9 ibu hamil dengan anemia, kemudian setelah sosialisasi sebanyak 8 ibu hamil dengan anemia berpengetahuan baik. Notoadmojo (2014) mengatakan pengetahuan merupakan hasil penginderaan manusia atau hasil tahu seseorang terhadap sesuatu yang bisa diamati dan dirasakanoleh indra yang dimilikinya (mata, hidung, telinga, dan sebagainya). Pengetahuan yang diperoleh seseorang dapat dipengaruhi oleh beberapa faktor yaitu usia, pendidikan, pekerjaan, kultur, pengalaman, informasi, dan lingkungan.

Hasil penelitian berdasarkan karakteristik pekerjaan didapati bahwa sebagian besar ibu hamil tidak bekerja yaitu berjumlah 7 responden (70\%) memiliki pengetahuan yang baik yaitu 5 responden (50\%). Ibu hamil yang tidak bekerja yaitu ibu yang berperan sebagai Ibu Rumah Tangga (IRT). Ibu Rumah Tangga memiliki banyak waktu luang untuk mencari informasi mengenai kesehatan dikarenakan bekerja di rumah tidak terikat seperti pekerjaan di luar rumah sehingga ibu dapat memperoleh pengetahuan baik dari media elektronik atau media cetak. Ibu juga akan selalu memiliki waktu untuk mengikuti kegiatan yang dapat menambah pengetahuan seperti kegiatan penyuluhan. Hasil penelitian ini tidak sejalan dengan teori yang diungkapkan oleh Wawan dan Dewi (2011) yang mengatakan bahwa kegiatan bekerja merupakan kegiatan yang menyita waktu tetapi memiliki pengaruh

\section{Journal of Community Engagement in} Health 
terhadap pengetahuan seseorang karena dengan bekerja ibu banyak bersosialisasi dengan sehingga pengetahuan yang diperoleh semakin mudah dan semakin banyak.

Hasil penelitian berdasarkan karakteristik usia diketahui bahwa sebagian besar ibu hamil berada dalam rentang usia 20-35 tahun. Hal ini menunjukkan bahwa sebagian besar ibu hamil di Puskesmas Sukorame berada dalam rentang usia yang masih reproduktif yaitu dari usia yang haid pertama sampai haid berakhir dan tidak beresiko tinggi. Usia merupakan salah satu faktor yang mempengaruhi hasil tau seseorang. Huclok (1998) (dalam Wawan dan Dewi, 2011) mengatakan bahwa semakin cukup umur, tingkat kedewasaan dan kekuatan seseorang akan lebih matang dalam berfikir dan bekerja. Kematangan tersebut akan sangat mempengaruhi terhadap kemampuan memahami apa yang ditangkap atau diterima oleh pancaindra dan cara menilai berdasarkan sudut pandang seseorang sehingga pengetahuan yang diperoleh semakin baik.

\section{KESIMPULAN} adalah:

Berdasarkan hasil sosialisasi dan pembahsan diatas maka kesimpulan yang dapat diambil

1. Tingkat pengetahuan ibu hamil sebelum dilakukan sosialisasi anemia mayoritas dalam kategori kurang yaitu sebanyak $90 \%$.

2. Tingkat pengetahuan ibu hamil setelah dilakukan sosialisasi anemia mayoritas dalam kategori baik yaitu sebanyak $80 \%$.

\section{REFERENSI}

Arikunto, S. (2013). Prosedur Penelitian Suatu Pendekatan Praktik. Edisi pertama. Rineka Cipta. Jakarta. Indonesia.

Badan Kependudukan dan Keluarga Berencana Nasional, Badan Pusat Statistik, Kementerian Kesehatan, MEASURE DHSICF International. (2012). Survei Demografi dan Kesehatan Indonesia (SDKI) 2012. http://chnrl.org/pelatihan-demografi/SDKI-2012.pdf. Diakses pada tanggal 10 Juli 2019 Pukul 07.28 WIB.

Badan Pusat Statistik. (2015). Survei Penduduk Antar Sensus 2015. http://microdata.bps.go.id/mikrodata/index.php. Diakses pada tanggal 10 Juli 2019 Pukul 09.00 WIB.

Departemen Kesehatan Republik Indonesia. (2015). Profil Kesehatan Indonesia 2015. http://www.depkes.go.id/resources/download/pusdatin/profil-kesehatan-indonesia/profil-kesehatanIndonesia-2015.pdf. Diakses pada tanggal 10 Juli 2019 Pukul 20.35 WIB.

Hidayah, \& Nurul, F. (2013). Faktor-Faktor Risiko Yang Mempengaruhi Kejadian Perdarahan Postpartum Primer Pada Ibu Bersalin Di RSUD Panembahan Senopati Bantul DIY Tahun 2012“e Skripsi. Program Studi Bidan Pendidik Jenjang DIV. Universitas Aisyiah Yogyakarta. Yogyakarta.

Irianti, B., dkk. (2014). Asuhan Kehamilan Berbasis Bukti. Edisi Pertama. Sagung Seto. Jakarta. Indonesia.

Kusumawati, \& Tri, B. (2012). Gambaran Tingkat Pengetahuan Ibu Hamil Tentang Anemia Pada Kehamilan Di Desa Gundik Wilayah Kerja Puskesmas Nailan Slahung Ponorogo. Karya Tulis Ilmiah. Program Studi Diploma III Kebidanan. Universitas Muhammadiyah. Ponorogo.

Prawirohardjo, S. (2009). Buku Acuan Nasional Pelayanan Kesehatan Maternal dan Neonatal. Edisi pertama. Bina Pustaka Sarwono Prawirohardjo. Jakarta. Indonesia.

\section{Journal of Community Engagement in Health}


Purbadewi, L., \& Ulvie, Y., N., S. (2013). Hubungan Tingkat Pengetahuan tentang Anemia Dengan Kejadian Anemia Pada Ibu Hamil. Jurnal Gizi Universitas Muhammdiyah semarang, Volume 2 Nomor 1. 